\title{
Propose Revised Standards for Academic Librarians
}

To the Editor:

As a member of the Academic Status Committee of ACRL I would like to comment on some of the points raised by individuals and groups regarding the Proposed Standards for Academic Librarians as they appeared in the October 1970 issue of CRL News. I speak for myself as an individual and not for the Committee, but it should be recognized that in the many discussions the Committee had in arriving at its decisions, these topics were of primary concern to all of us.

First of all, it was the intent of our Committee to prepare standards for academic librarians only. ACRL members have gone on record as favoring action which would most clearly align them with the faculties of the institutions they serve. The common practice of fragmenting this group of professionals from the rest of the instructional faculty has resulted in many of the problems which have made the development of more precise standards mandatory. The intent of the document throughout has been to stress those elements which librarians in an academic community share with other members of the faculty. It is understood that we depart from the orientation of public and special librarians, or any other group of librarians which does not operate in a collegial environment.

If such standards are in conflict with other ALA standards, perhaps it is time to recognize the inadequacy of the notion that all librarians in any type of library can or should fit into the same organizational patterns or educational requirements. Acceptance of this document would mean that certain matters presently under the purview of LAD, for example, would no longer be, but would be the exclusive concern of ACRL.

There seems to be some uneasiness about the equating of two master's degrees with a Ph.D. Perhaps the rewording developed at the November 1970 meeting in Chicago will alleviate some of this discomfort. (See revised Standards.) Admittedly, the Committee was caught in the dilemma of recognizing that this standard appeared to denigrate the Ph.D. in library science and to make it seem that we did not favor the pursuit of such a degree. This was not the case. The Committee was of the opinion that Ph.D. programs in library science needed to be expanded and strengthened and that more practitioners should be encouraged to go on for the doctorate. ( To this end we drafted a resolution addressed to the Department of Health, Education, and Welfare calling for restoration of funds for doctoral study under Title II, Part B of the Higher Education Act of 1965.) At this point, our professional schools are sim- ply not tooled to produce large numbers of doctorates, and it would be unrealistic and unfair to require the Ph.D. as terminal under these conditions. The sixth year master's programs are another problem, and I do not feel qualified to address myself to this mystery, except to comment that it would seem to represent the profession's collective failure, once more, to clearly identify its standards and educational requirements.

However, I do not share the concern of those persons who feel that the requirement of two master's degrees offers credentials markedly inferior to the rest of the faculty. As has been noted, we have the examples of certain disciplines where the Ph.D. is not necessarily the terminal degree and whose members are still fully recognized as faculty. I refer not only to fine arts, engineering, and so forth, but also to one whose membership is also "dominated" by women, namely, nursing. In addition, I believe that the requirement for subject expertise as well as proficiency in librarianship places rather extraordinary demands on the librarian. I cannot view it as a "watering down" of standards. When we talk about subject expertise, and a subject master's, it is not assumed that proficiency begins and ends with the earning of the degree. It means working under the injunction to continue to be abreast of both fields-librarianship and the other subject discipline. It means keeping up in the literature of both, maintaining professional contacts and memberships in both, and pursuing research that is relevant to either or both.

In the California state colleges, the statewide academic senate voted to give librarians faculty status. The success of the librarians' case with the faculty rested very strongly on the premise that subject expertise on the part of the librarians would enable them to participate as full faculty members in the educational program. The faculty, in short, liked the idea that there would be an informed library staff, informed in the sense of identifying and fulfilling library needs for the given subject areas. We were able to gain the faculty's acceptance by offering as part of our "credentials" an acceptable level of achievement in a subject discipline, in other words, a second master's degree.

Questions arose as to whether peer judgment can mean exclusively librarians inasmuch as the library is a unit that services an entire campus, and faculty from other departments might have a vested interest in evaluating total performance. The intent of the Committee here was to let the local campus policy dictate what is meant by "peer review." In some schools, there are provisions for interdepartmental review of 
faculty. In others, personnel committees are formed entirely within the school or department. The strengths or weaknesses of any department can have wider reverberations in the total educational program than those immediately apparent in that department. We favor librarians being guided by the general personnel procedures established for the rest of the faculty.

The question of faculty rank and titles was one of the most discussed and debated issues in the document. Arguments ranged from the "honorableness" of the profession and being proud to be a Iibrarian, to the possibility of developing analogous titles which would "equate" in some way but retain the uniqueness of the occupation. The prevailing judgment, however, was that anything separate was bound to be less than equal and that the most serious intent could be shown by calling for the same classification, with the same titles, ranks, and steps.

The statement on library governance has excited much interest and a certain degree of pessimism, mainly from library administrators. Certainly, this standard, if accepted, would require the greatest amount of reorientation from present practices, both for administrators and nonadministrators. While there are differences between libraries and other academic departments, the stressing of those differences has caused multiple difficulties for academic librarians. We would stress the analogies rather than the differences. The concepts are not new. They have permeated the literature for many years. A library, for example, would function as a school or college, depending upon its size and its relationship to the total campus structure. The position of head librarian would be analogous to a dean, division head, or whatever the nomenclature of the institution provides for that administrative level. Within this structure, department chairmen, either elected or appointed (again depending on local practice) would have administrative responsibility for the organizational unit. Decisions within this administrative framework, however, would be based on communication and group action.

We are recommending this standard not because of blind allherence to faculty tradition for its own sake, but also in recognition that library management has generally failed to respond much to the great amount of work done in the bchavioral sciences in motivational analysis, personnel practices, and group theory. Business and industry, indeed, have come to recognize that organizational goals are better fulfilled when they are compatible with individuals goals. The collegial model provides a framework for academic librarians to fulfill both their personal needs to achieve the autonomy of true professionals and to integrate their achievements with the total educational process of their institutions. Conceptual frameworks based on rigid hierarchical personnel patterns will have to be relinquished in favor of a participatory enterprise, with emphasis on professional expertise and shared values common to the group, and rewards based on professional excellence. In short, we believe such library governance to be consistent with the most widely accepted contemporary theories of effective management.

Whether the Proposed Standards are adopted or not will depend on the vote of the members of ACRL. If adopted, their success will depend upon the cooperation and active support of all academic librarians. I believe the endorsement and acceptance of such standards would be truly a vote of confidence in the profession.Beverly Johnson, Serials Librarian (on leave), San Diego State College.

\section{Revision in the Proposed Stanidards For Faculty Status}

1. Professional Responsibilities and Self-Determination. Each librarian should be assigned general responsibilities within his particular area of competence. He should have maximum possible latitude in fulfilling these responsibilities. However, the degree to which he has fulfilled them should be regularly and rigorously reviewed. A necessary element of this review must be an appraisal by a committee of peers who have access to all available evidence.

2. Library Governance. College and university libraries should adopt an academic form of governance. The librarians should form a library faculty whose role and authority is similar to that of the faculties of a college, of the faculty of a school or a department.

3. College and University Governance. Librarians should be cligible for membership in the academic senate or equivalent body at their college or university on the same basis as other faculty.

4. Education. Because of the dual demands upon librarians for both professional and subject field competence, two master's degrees -one in librarianship and one in a relevant subject field-shall be the minimal educational requirement for tenure for all librarians appointed after the adoption of these standards by ACRI.

5. Compensation. The salary scale for librarians should be the same as that for other academic categories with equivalent education and experience. Librarians should normally be appointed for the academic year. If a librarian is expected to work through the summer session, his salary scale should be adjusted similarly to the summer session scale of other faculty at his college or university.

6. Tenure. Librarians should be covered by tenure provisions the same as those of other 
faculty. In the pretenure period, librarians should be covered by written contracts or agreements the same as those of other faculty.

7. Promotion. Librarians should be promoted through ranks and steps on the basis of their academic proficiency and professional effectiveness. A peer review system similar to that used by other faculty is the primary basis of judgment in the promotion process for academic librarians. The librarians' promotion ladder should have the same titles, ranks, and steps as that of the faculty.
8. Leaves. Sabbatical and other research leaves should be available to librarians on the same basis and with the same requirements as they are available to faculty.

9. Research Funds. Librarians should have access to funding for research projects on the same basis as other faculty.

10. Academic Freedom. Librarians in colleges and universities must have the protection of academic freedom. Library resources and the professional judgment of librarians must not be subject to censorship.

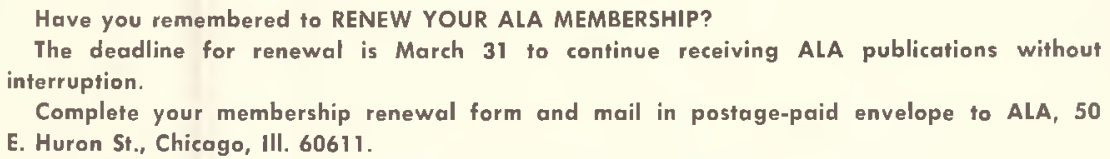

\section{From Inside the DLP}

\section{By Dr. Katharine M. Stokes}

College and University Library Specialist, Training and Resources Branch, Division of Library Programs, Bureau of Libraries and Educational Technology, U.S. Office of Education, Washington, D.C. 20202.

In the annual report of a library in the Southeast I found an account of just the sort of impact we hope federal funds can make on a campus. Quoting from the report:

What started out to be one of the gloomy spots of the year turned around and became one of the high points of the year. I am speaking of the drive to secure funds to meet maintenance of effort for the library's federal grant application. It was evident early in the fiscal year that the library budget would fall some $\$ 9,500$ short in meeting maintenance of effort requirements. As the deadline approached a gift of $\$ 5,000$ from the Guaranty Banks through the . . alumni Foundation gave us hopes that the requirement would be met. Four days prior to the deadline a drive to secure the additional $\$ 4,500$ was started by the student government association, friends of the library, and interested faculty and students. The response was overwhelming. Contributions came from students, faculty, and organizations on campus. Contributions also came from individuals, service clubs, and businesses from ... the surrounding area. The contributions made it possible for the library to qualify for a grant of $\$ 7,023$ for fiscal $1970-71$. I think this crash program brought knowledge to those who had been apathetic before as to the financial condi- tion of the university as a whole and the library in particular. The publicity we received and the response made toward the library was most gratifying.

The librarian of this university demonstrated perfectly the way federal "seed money" can be used to produce improved nonfederal support. His report shows that he makes good use of all parts of the Title II-A (Higher Education Act) college library resources program. The maintenance of effort project made the library eligible to receive basic and supplemental grants in 1970 , the only types available this year. The previous year, however, the library was a member of a consortium of eight libraries from two neighboring states which obtained a Title II-A Special Purpose Type C grant for the purchase of microfilm research materials to be centrally cataloged and stored for joint use. None of these materials would be used constantly on each campus, but all of them will be ready to meet sudden needs of faculty or graduate students, easily and quickly available by interlibrary loan.

The librarian writing the report also describes his experience as a participant in an institute on library automation in his state, funded by Title II-B (Higher Education Act).

While he does not mention the titles for these federal projects we can identify them by matching our records to his accounts. It's with real pleasure that we find such encouraging news of how federal grants have aided libraries and librarians. 